\title{
Distribution of IL28B Polymorphism in a Cohort of Italians and Immigrants with HCV Infection: Association with Viraemia, Stage of Fibrosis and Response to Treatment
}

\author{
L. Nosotti ${ }^{1}$ - A. Petrelli ${ }^{1}$ - D. Genovese ${ }^{2} \cdot$ S. Catone ${ }^{2}$ C. Argentini ${ }^{2}$ -

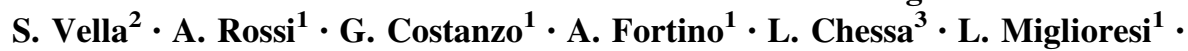 \\ C. Mirisola ${ }^{1}$
}

(C) Springer Science+Business Media New York 2016

\begin{abstract}
Aims of the study are to investigate, in a cohort of patients affected by HCV chronic hepatitis with genotypes 1 and 4, the prevalence of interleukin 28B (IL28B) genotypes, the possible association between IL28B polymorphism and severity of liver damage, the role of IL28B $\mathrm{CC}$ as a predictor of outcome. 365 patients with $\mathrm{HCV}$ infection were observed between 2013 and 2014. Demographic, virological, biochemical, and genetic characteristics of each patient were investigated. Liver fibrosis was assessed by transient elastometry. Mean age of the patients (72.9\% males, $27.1 \%$ females) is 50 years. $91.5 \% \%$ of patients are Caucasian, $8.5 \%$ African. In the patients with HCV1 and HCV4 a higher frequency of IL28B CT is observed with a prevalence of 52.1 and $61.8 \%$ respectively. As regards ethnic group, African people have a prevalence of $35.5 \%$ for $\mathrm{CC}$, while Caucasians have a prevalence of $23.8 \%$ for CC. In our cohort, IL28B polymorphism does not show significant differences among ethnic groups and in HCV1 and HCV4 genotypes. As described in literature, IL28B CC genotype is confirmed as predictor of sustained virological response in both Caucasians and Africans. A significant correlation between liver fibrosis and IL28B polymorphism emerges.
\end{abstract}

Keywords HCV chronic hepatitis · HCV1 and HCV4 genotypes $\cdot$ IL28B polymorphism

\footnotetext{
L. Nosotti

1.nosotti@virgilio.it

1 National Institute for Health, Migration and Poverty (NIHMP), Via San Gallicano 25/a, 00153 Rome, Italy

2 National Institute for Health (NIH), Rome, Italy

3 Center for the Study of Liver Diseases, University of Cagliari, Cagliari, Italy
}

\section{Background}

HCV infection affects about 170 million people in the world and is an important world health problem [1]. A number of factors associated with hepatitis $\mathrm{C}$ virus or with the infected host may predict the outcome of chronic patients under treatment. Most important virus-related predictive factors are stage of fibrosis and basal viral load whereas main host-related factors are stage of fibrosis, age, insulin resistance and ethnic group. Beside those factors that have been used for many years for identifying patients to be treated, a number of host's genetic polymorphisms were recently considered to be associated with immune response and appear to have a role in the natural history of the infection. Among them, two single nucleotide polymorphisms (SNPs) on the gene IL28B that codes for the cytokine IFN-lambda on chromosome 19 were investigated. Those polymorphisms were associated with virus spontaneous clearance and pegylated interferon and ribavirin treatment-induced clearance [2,3]. The results of several studies confirmed the association between IL28B $\mathrm{CC}$ and positive response to antiviral therapy for $\mathrm{HCV}$ infection, particularly with genotypes HCV1 and HCV4 and to a lesser extent with genotypes HCV3 and HCV4 [3-8].

The most frequently observed HCV genotype in Europe and Italy is genotype 1, whereas in Africa and Middle East it is the genotype 4 . Genotype 4 has recently spread in South Europe and Italy, especially among intravenous drug users and immigrants $[9,10]$.

Among patients of the National Institute for Health, Migration and Poverty (NIHMP) outpatient department there are many African immigrants, all with HCV4 genotype, whereas among Caucasian patients (both Italian and European immigrants) genotype 1 is highly prevalent. 
Some studies indicate a different IL28B genetic polymorphism in individuals with HCV1 genotype compared with genotypes HCV2 and HCV3. In particular, favourable genotype IL28B CC appear to be most frequently observed in genotypes HCV2 and HCV3 than in genotype HCV1 [11-16]. According to a recent study [17] on Italian patients, the frequency of IL28BCC in individuals with HCV1 resulted similar to those with HCV4 (28.4 and $24.2 \%$ respectively).

Furthermore, conflicting data are observed as regards the relation between IL28B polymorphism and basal viraemia. In facts, studies $[2,17]$ conducted on patients with genotype HCV1 show an association between favourable genotype IL28BCC and higher basal HCV-RNA viraemia levels than those observed on patients with IL28B non-CC genotypes. On the contrary, a study [7] conducted on patients with genotype HCV4 does not show any significant association between basal viraemia and IL28B polymorphism.

Also as regards the association between genetic variations and extent of liver fibrosis, conflicting scientific studies exist. In a number of researches [18-21] favourable genotype IL28B CC appears to be related with advanced stages of fibrosis; a study [22] shows a relation of advanced stage of fibrosis with IL28B unfavourable genotypes (non CC) and still others $[7,17,23,24]$ do not show any association between IL28B polymorphism and severity of liver damage.

\section{Conceptual Framework}

\section{Objectives of the Study Are}

1. To assess the prevalence of IL28B genotypes in a sample of Caucasian and African patients affected by HCV chronic hepatitis with genotypes 1 and 4 .

2. To investigate the existence of an association between basal viraemia and severity of liver damage (significant predictive factors of response to therapy) and IL28B CC genotype in patients with genotypes HCV1 and HCV4.

3. To verify the role of IL28B genetic polymorphism as predictive factor of rapid virological response to treatment (RVR), of end of treatment response (ETR) and of sustained virological response (SVR) in HCVinfected Caucasian and African patients with genotypes 1 and 4 treated with pegylated interferon and ribavirin.

\section{Methods}

\section{Participants}

This is a prevalence study conducted on naif, under treatment or treated patients with chronic genotype 1 and 4 $\mathrm{HCV}$ infection. A total of 365 patients with chronic $\mathrm{HCV}$ single infection were enrolled between 2013 and 2014: 77 at the NIHMP Outpatient Department and 288 at the Centre for the study of liver diseases of the Department of Internal Medicine of the University of Cagliari.

\section{Data Collection and Measures}

Demographic, virological, biochemical, and genetic characteristics of each patient were investigated. Liver fibrosis was investigated with liver elastometry (Fibroscan). Threshold values were: (a) stiffness from 4.7 to $8.6 \mathrm{Kpa}$ : non-significant fibrosis; (b) stiffness from $8.7 \mathrm{Kpa}$ : significant fibrosis (from $12.5 \mathrm{Kpa}$ with cirrhosis). All whole blood samples were kept and evaluated at the Drugs Department of the Italian Higher Institute of Health (ISS) through a TaqMan device with allelic discrimination assay or direct sequencing. HCV genotype and quantitative HCV RNA were evaluated. Units of measurement of HCV-RNA were IU/ml. A sample of serum of each patient was kept.

59 patients underwent pegylated interferon plus ribavirin treatment.

\section{Statistical Analysis}

The association between genetic variables of the IL28B genotype and $\mathrm{HCV}$ genotype was investigated through bivariate statistical analysis and Chi square test for assessing statistical significance. Association was tested for rs12979860 (CC, CT, TT) and for rs8099917 (TT, GT, GG). For subsequent tests, IL28B genotype was grouped in two categories: CC and CT-TT (rs12979860), TT and GTGG (rs8099917). Association between IL28B genotype and liver fibrosis, grouped in two cathegories $(\leq 8.6,>8.6 \mathrm{Kpa})$ was investigated with the Chi square test. Association between IL28B genotype and basal viraemia was assessed through the $t$ test with logarithm of observed values for standardising distribution. Multivaried logistic models were tested for assessing the predictive role of IL28B genetic polymorphism on positive RVR, ETR and SVR response. They were adjusted by gender, age $(\leq 35,36-55$, $\geq 56)$, basal viraemia $(<600,000 \mathrm{IU} / \mathrm{ml}, \geq 600,000 \mathrm{IU} / \mathrm{ml})$ and liver fibrosis $(\leq 8.6, \geq 8.7 \mathrm{Kpa})$. IL28B genetic polymorphism was tested with rs 12979860 (CC vs. CT-TT) and rs8099917 (TT vs. GT-GG).

The research has been approved by an ethics review committee.

\section{Results}

The mean age of the $365 \mathrm{HCV}$-infected patients observed ( $72.9 \%$ males, $27.1 \%$ females), is 50 years (48.8 years among men and 53.8 among women, standard 
deviation \pm 11.8 ). $83.8 \%$ of patients are Italian, $7.7 \%$ are from other EU countries, $8.5 \%$ from Africa (Table 1).

IL28B genotype and rs12979860 is not significantly related with HCV genotype and significantly related with ethnic group. In the total 365 patients with HCV1 and 4 a higher frequency of IL28B CT is observed with a prevalence of 52.1 and $61.8 \%$ respectively. As regards ethnic group, African people have a prevalence of $35.5 \%$ for CC and CT and $29 \%$ for TT. Caucasians (Italians and Caucasian immigrants) have a prevalence of $23.8 \%$ for CC, $58.1 \%$ for CT and $18.1 \%$ for TT $(p=0.05)$. rs 8099917 was assessed, it results significantly related with $\mathrm{HCV}$ genotype $(p<0.001)$ and not with ethnic group (Table 2$)$.

In patients with HCV1 and HCV4 genotypes an association between liver fibrosis and distribution of IL28B genotype is observed. It is statistically significant in the distribution of rs12979860 and rs8099917 $(p<0.05)$ (Table 3). As regards rs 12979860 , a higher number of patients with liver fibrosis levels higher than $8.7 \mathrm{Kpa}$ is observed among patients with CT-TT genotypes (23.2\%). As regards rs8099917, this is observed among patients with GG-GT genotypes $(23.9 \%)$.

No statistical significance is observed in the correlation between pre-treatment basal viraemia levels and distribution of IL28B genetic polymorphism: rs12979860 (CC: $1,745,751.96 \pm 2,590,263.06 ; \quad$ CT-TT $1,544,395.68 \pm$ 2,918,738.77), $\quad$ rs8099917 (TT: $1,818,110.39 \pm$ 2,496,714.91; GG-GT: $1,439,114.54 \pm 3,054,716.73$ ) (Fig. 1).

Multivariate analysis on rs12979860 shows that the presence of IL28B CC genotype increases the possibility of positive RVR (OR 60.46; CI 14.96-337.23), ETR (OR 15.24 CI 3.85-104.60) and SVR (OR 15.24 CI 3.85-104.60), even though confidence intervals are wide (Table 4).

Age, gender, basal viraemia and liver fibrosis were taken into account. Similar results are observed when considering rs8099917, where genotype TT increases the possibility of positive RVR (OR 6.74; CI 2.72-18.06), ETR (OR 5.88; CI 2.25-17.44) and SVR (OR 5.88; CI 2.25-17.44).

\section{Discussion}

The study shows that in the observed cohort, the HCV4 genotype is the most frequent, with a prevalence higher than the one described in literature in Europe and Italy $(55.2 \%$ vs. about $5-10 \%)[25,26]$.

This distribution cannot be explained by the presence of African patients, in which the prevailing genotype is the genotype $4[9,10]$, since in our case they represent only $8.5 \%$.

The IL28B genotype seems to have a significantly different distribution between Africans and Caucasians (which most frequently have the IL28 CT genotype); this fact however is not statistically significant after the study of confidence intervals, because of the discrepancy between the higher number of Caucasian patients compared to the African ones in our cohort.

Regarding the IL28B CC genotype's frequency in the HCV1 and HCV4 genotypes, we did not observe a statistically significant difference in the distribution (26.1 vs. $23.0 \%$ ) in agreement with a recent study [17].

However the low percentage of IL28BCC in the HCV1 and HCV4 genotypes contrasts with the high frequency of IL28BCC observed in other studies in the HCV2 and HCV3 genotypes (respectively 39 and $36 \%$ in the cited study of Mottola et al.). This could explain the better response to antiviral therapy with pegylated interferon and ribavirin in the HCV2 and HCV3 genotypes compared to the one obtained in the HCV1 and HCV4 genotypes.

Furthermore a significant correlation between liver fibrosis and IL28B polymorphism emerges in agreement with other studies [7, 17, 23], but in contrast with the study of Ydreborg [21], that was done in patients with HCV3 genotype.

Our findings are consistent with the results of Tamaki et al. [27], who showed that patients with IL28B genotypes TG/GG had higher fibrosis progression than patients with genotypes IL28BTT; furthermore, they demonstrated that IL28B TG/TT is an independent predictor of rapid fibrosis progression in patients with chronic hepatitis $\mathrm{C}$ non responders to interferon-based therapy.
Table 1 Distribution of patients by gender and area of origin

\begin{tabular}{|c|c|c|c|c|c|c|c|}
\hline \multirow[t]{3}{*}{ Area of origin } & \multicolumn{4}{|c|}{ Gender } & & & \\
\hline & \multicolumn{2}{|l|}{ Men } & \multicolumn{2}{|c|}{ Women } & \multicolumn{3}{|c|}{ Total } \\
\hline & $\mathrm{n}$ & $\%$ & $\mathrm{n}$ & $\%$ & $\mathrm{n}$ & $\%$ & $p$ value \\
\hline Italy & 223 & 83.8 & 83 & 83.8 & 306 & 83.8 & $p<0.001$ \\
\hline Other EU countries & 13 & 4.9 & 15 & 15.2 & 28 & 7.7 & \\
\hline Africa & 30 & 11.3 & 1 & 1.0 & 31 & 8.5 & \\
\hline Total & 266 & 100 & 99 & 100 & 365 & 100 & \\
\hline Mean age $( \pm$ SD $)$ & \multicolumn{2}{|c|}{$48.8( \pm 10.4)$} & \multicolumn{2}{|c|}{$53.8( \pm 14.2)$} & \multicolumn{2}{|c|}{$50.1( \pm 11.8)$} & $p<0.001$ \\
\hline
\end{tabular}


Table 2 Distribution of HCV genotype and ethnic groups according to the genotype IL28B

\begin{tabular}{|c|c|c|c|c|c|c|c|c|c|c|c|c|c|c|c|c|c|c|}
\hline \multirow[t]{4}{*}{ Genotype IL28B } & \multicolumn{9}{|c|}{ HCV Genotype } & \multicolumn{9}{|c|}{ Ethnic group } \\
\hline & \multicolumn{4}{|l|}{1} & \multicolumn{4}{|l|}{4} & \multirow[t]{3}{*}{$p$ value } & \multicolumn{4}{|c|}{ Africans } & \multicolumn{4}{|c|}{$\begin{array}{l}\text { Italians and other } \\
\text { Caucasians }\end{array}$} & \multirow[t]{3}{*}{$p$ value } \\
\hline & \multirow[t]{2}{*}{$\mathrm{n}$} & \multirow[t]{2}{*}{$\%$} & \multicolumn{2}{|c|}{ IC95\% } & \multirow[t]{2}{*}{$\mathrm{n}$} & \multirow[t]{2}{*}{$\%$} & \multicolumn{2}{|c|}{ IC95\% } & & \multirow[t]{2}{*}{$\mathrm{n}$} & \multirow[t]{2}{*}{$\%$} & \multicolumn{2}{|c|}{ IC95 \% } & \multirow[t]{2}{*}{$\mathrm{n}$} & \multirow[t]{2}{*}{$\%$} & \multicolumn{2}{|c|}{ IC95 \% } & \\
\hline & & & $\mathrm{L}$ & $\mathrm{U}$ & & & $\mathrm{L}$ & $\mathrm{U}$ & & & & $\mathrm{L}$ & $\mathrm{U}$ & & & $\mathrm{L}$ & $\mathrm{U}$ & \\
\hline \multicolumn{19}{|l|}{ SNP 860} \\
\hline $\mathrm{CC}$ & 55 & 26.1 & 20.1 & 32.0 & 35 & 23.0 & 16.3 & 29.7 & & 11 & 35.5 & 18.6 & 52.3 & 79 & 23.8 & 19.2 & 28.4 & $\mathrm{p}<0.05$ \\
\hline $\mathrm{CT}$ & 110 & 52.1 & 45.4 & 58.9 & 94 & 61.8 & 54.1 & 69.6 & & 11 & 35.5 & 18.6 & 52.3 & 193 & 58.1 & 52.8 & 63.4 & \\
\hline $\mathrm{TT}$ & 46 & 21.8 & 16.2 & 27.4 & 23 & 15.1 & 9.4 & 20.8 & & 9 & 29.0 & 13.1 & 45.0 & 60 & 18.1 & 13.9 & 22.2 & \\
\hline Total & 211 & 100 & & & 152 & 100 & & & & 31 & 100 & & & 332 & 100 & & & \\
\hline \multicolumn{19}{|l|}{ Missing $=2$} \\
\hline \multicolumn{19}{|l|}{ SNP 917} \\
\hline $\mathrm{TT}$ & 93 & 44.3 & 37.6 & 51.0 & 55 & 36.2 & 28.5 & 43.8 & $\mathrm{p}<0.001$ & 14 & 45.2 & 27.6 & 62.7 & 134 & 40.5 & 35.2 & 45.8 & \\
\hline GT & 97 & 46.2 & 39.4 & 52.9 & 95 & 62.5 & 54.8 & 70.2 & & 16 & 51.6 & 34.0 & 69.2 & 176 & 53.2 & 47.8 & 58.5 & \\
\hline GG & 20 & 9.5 & 5.6 & 13.5 & 2 & 1.3 & 0.0 & 3.1 & & 1 & 3.2 & 0.0 & 9.4 & 21 & 6.3 & 3.7 & 9.0 & \\
\hline Total & 210 & 100 & & & 152 & 100 & & & & 31 & 100 & & & 331 & 100 & & & \\
\hline Missing $=3$ & & & & & & & & & & & & & & & & & & \\
\hline
\end{tabular}

Table 3 Distribution of IL28B genotype for cathegories of liver fibrosis

\begin{tabular}{|c|c|c|c|c|c|c|c|c|c|c|}
\hline \multirow[t]{3}{*}{ Liver fibrosis } & \multicolumn{5}{|c|}{ SNP 860} & \multicolumn{5}{|c|}{ SNP 917} \\
\hline & \multicolumn{2}{|l|}{$\mathrm{CC}$} & \multicolumn{2}{|c|}{ CT-TT } & \multirow[t]{2}{*}{$p$ value } & \multicolumn{2}{|l|}{ TT } & \multicolumn{2}{|c|}{ GG-GT } & \multirow[t]{2}{*}{$p$ value } \\
\hline & $\mathrm{n}$ & $\%$ & $\mathrm{n}$ & $\%$ & & $\mathrm{n}$ & $\%$ & $\mathrm{n}$ & $\%$ & \\
\hline$\leq 8.6$ & 78 & 87.6 & 209 & 76.8 & $p<0.05$ & 125 & 85.0 & 162 & 76.1 & $p<0.05$ \\
\hline$\geq 8.7$ & 11 & 12.4 & 63 & 23.2 & & 22 & 15.0 & 51 & 23.9 & \\
\hline \multirow[t]{2}{*}{ Total } & 89 & 100 & 272 & 100 & & 147 & 100 & 213 & 100 & \\
\hline & \multicolumn{5}{|c|}{ Missing $=4$} & \multicolumn{4}{|c|}{ Missing $=5$} & \\
\hline
\end{tabular}

Although other studies are needed to confirm these results, the relationship found between liver fibrosis and IL28B polymorphism could be very important for predicting progression of liver disease in patients waiting for the new therapies.

The use of IL28B as genetic predictor could assess the risk of fibrosis progression in patients with chronic hepatitis $\mathrm{C}$ requiring treatment with new generation DAAs.

In limited-resource healthcare systems this could help to optimize HCV therapy, providing new DAAs to patients with severe liver damage or with prediction of rapid progression of fibrosis, thus deferring treatment or prescribing dual therapy with Peg-IFN and ribavirin to patients with less advanced liver disease or with genetic prediction of slow progression of fibrosis.

Between the levels of basal viraemia and the distribution of the IL28B genotype the relation is not significant, in contrast with some studies [2, 4, 17] in which the high viraemic levels were related to the favorable IL28B genotype, but in agreement with other studies [7, 28] in which the relation between the basal viral load and the IL28B genetic polymorphism was not statistically significant.

Regarding the response to therapy, the IL28B CC genotype predicts RVR, ETR and SVR, and predicts SVR in both Caucasians and Africans with genotype 1 and 4 subjected to dual therapy with pegylated interferon and ribavirin, confirming what is described in literature [3-7].

One of the main problems in the dual therapy with pegylated interferon and ribavirin is certainly the presence of various side-effects.

Studies have been recently published, including a clinical trial [29], in which the efficacy of pegylated interferon lambda-1a in replacement of interferon alpha is evaluated. Peginterferon-lambda seems to have a slightly higher efficacy than peginterferon alpha but with minor extrahepatic side-effects, and especially a drastically reduced number of haematological complications. 

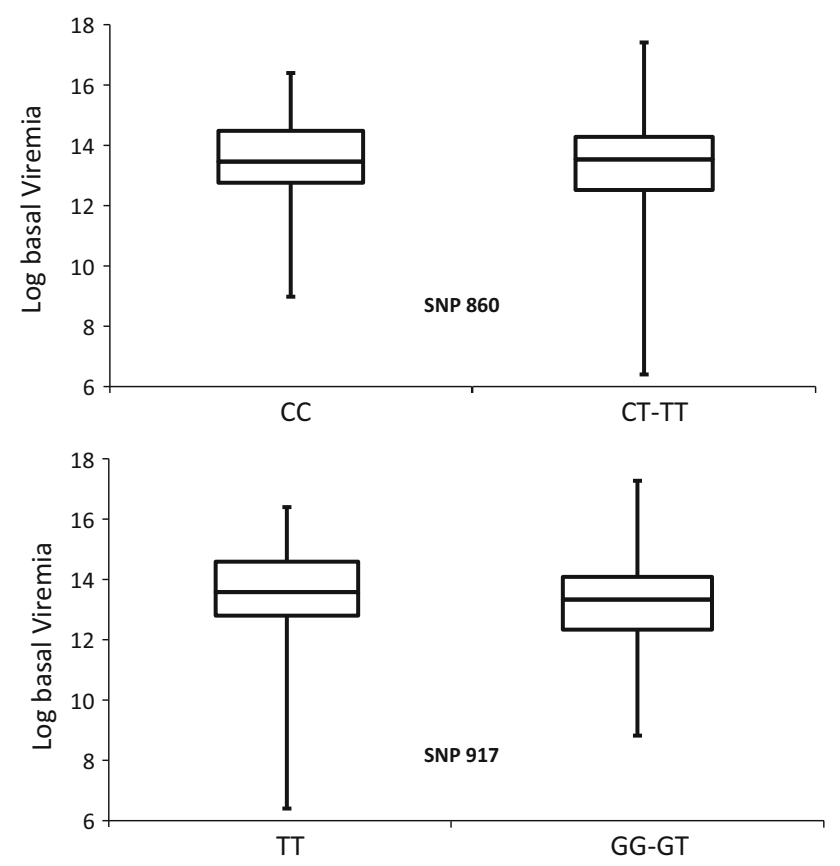

Fig. 1 Pre-treatment basal viremia levels and distribution of IL28B genetic polymorphism

It is important to remember that interferon lambda is nothing other than the interleukin 28 , and this reinforces the need to study this group of genes for their direct effect in patients with chronic hepatitis $\mathrm{C}$ as well as for their efficacy as predictors of response to therapy.

It is also evident that the reduction of the side-effects that can be obtained by the introduction of interferon lambda could favor the choice of the therapy with interferon, which is now opposed by the majority of patients and by many specialists, and is becoming a low-cost alternative to the therapy with new inhibitor medications especially in cases regarding favorable genetic markers.

IL28B polymorphism however keeps its predictive power even with triple therapy with direct acting antiviral agents (DAAs) + peginterferon, and may also have a role with the new interferon-free therapies.

For the HCV infection treatment, a new medicine has recently been approved by the FDA and EMA: sofosbuvir, a HCV NS5B polymerase inhibitor with a pangenotopic spectrum of activity, which has raised the percentage of SVR above $90 \%$, without any significant differences between the different genotypes [30,31].

New HCV DAAs have recently been approved by the FDA and EMA: simeprevir, a NS3/4A protease inhibitor for patients infected with HCV genotype 1 and 4; daclatasvir, an inhibitor of NS5A which has an antiviral pangenotipic activity; ledipasvir, a NS5A inhibitor available in a two-drug fixed combination with sofosbuvir for patients infected with HCV genotype 1 and 4 [32-36].

Another drug recently licensed in EU for use in HCV genotypes 1 and 4 is a fixed combination of paritaprevir (an NS3-4A protease inhibitor ritonavir-boosted), ombitasvir (an NS5A inhibitor) and dasabuvir (a non-nucleoside inhibitor of HCV RNA dependent RNA polymerase) [37].

However these medicines are very expensive, a fundamental aspect in limited-resource healthcare systems; therefore the cost-effectiveness shall be evaluated, and it could limit the availability of the medicine for patients with chronic HCV infection. The large population of patients that can be treated with the new DAAs and the high cost of every single treatment cause great concern regarding the capacity of the healthcare system to carry the burden.

In conclusion, whereas in the past only the standard dual therapy with pegylated-interferon and ribavirin was available, now many new therapies have been approved for use; however in patients with HCV genotype 1 and 4, the pegylated-interferon will still be used for a certain period of time in combination with the new medicines, certainly in patients with low-grade fibrosis [36, 37].

Furthermore, in limited-resource healthcare systems, it is necessary to consider that since the new DAAs are really expensive, in order to limit the costs, the dual therapy (pegylated-interferon + ribavirin) could keep its role and be reserved to certain categories of patients.

The assessment of the IL28B polymorphism could therefore be a valid instrument for a personalized therapy in patients with chronic HCV1 and HCV4-related liver disease: individuals with IL28B favorable genotype (CC) and low-grade fibrosis could be treated with a standard dual therapy and where needed with a short-term therapy.

Table 4 Logistic model for positive ETR, SVR e RVR. Odds Ratios (OR) and Confidence Intervals $95 \%$

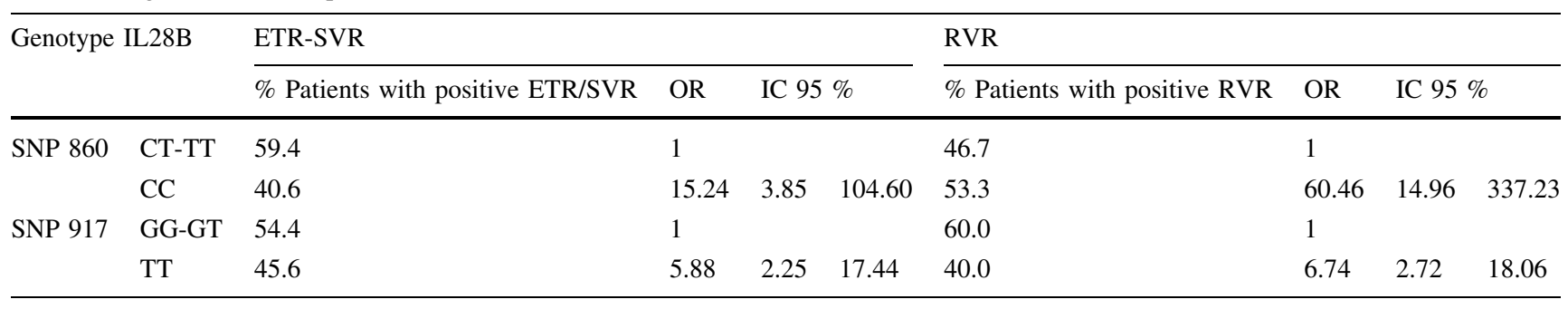


In individuals with IL28B unfavorable genotypes (CT or TT) and advanced fibrosis vice versa, it could be preferable to start the therapy with new antiviral medicines available.

\section{New Contribution to the Literature}

- In our cohort, the HCV 4 genotype is the most frequently observed, with a higher prevalence compared to that described in literature in Italy (55.2 vs. $10 \%)$; IL28B polymorphism does not show significant differences among ethnic groups and in HCV1 and HCV4 genotypes.

- In our study a significant correlation between liver fibrosis and IL28B polymorphism emerges in Italian and immigrant patients with chronic hepatitis $\mathrm{C}$ and HCV1 and HCV4 genotype

- We found no significant correlation between the levels of basal viraemia and the distribution of the IL28B genotype in both Caucasian and African patients with HCV1 and HCV4 genotype

- Regarding the response to therapy, IL28B CC genotype predicts rapid virological response (RVR), end of treatment response (ETR) and sustained virological response (SVR) in both Caucasians and Africans with HCV1 and HCV4 genotype subjected to dual therapy with pegylated interferon and ribavirin

\section{Compliance with Ethical Standards}

\section{Conflict of interest None.}

\section{References}

1. Lavanchy D. The global burden of hepatitis C. Liver Int. 2009;29(Suppl. 1):74-81.

2. Thompson AJ, Muir A, Sulkowski M, Ge D, Fellay J, Shianna $\mathrm{KV}$, Urban T, et al. IL28B polymorphism improves viral kinetics and is the strongest pre-treatment predictor of sustained virologic response in genotype 1 hepatitis C virus. Gastroenterology. 2010;139:120-9.

3. Thomas DL, Thio CL, Martin MP, Qi Y, Ge D, O'Huigin C, Kidd J, Kidd K, Khakoo SI, Alexander G, Goedert JJ, Kirk GD, Donfield SM, Rosen HR, Tobler LH, Busch MP, Mc Hutchison JG, Goldstein DB, Carrington M. Genetic variation in IL28B and spontaneous clearance of hepatitis C virus. Nature. 2009;461: 798-801.

4. Ge D, Fellay J, Thompson AJ, et al. Genetic variation in IL28B predicts hepatitis $\mathrm{C}$ treatment-induced viral clearance. Nature. 2009;461:399-401.

5. Suppiah V, Maldovam M, Ahlenstiel G, Berg T, Weltman M, Abate ML, Bassendine M, et al. IL 28B is associated with response to chronic hepatitis $\mathrm{C}$ interferon-alpha and ribavirin therapy. Nat Genet. 2009;41:1100-4.

6. Tanaka Y, Nishida N, Sugiyama M, Kurosaki M, Matsuura K, Sakmoto N, Nakagawa M, Korenaga M, et al. Genome-wide association of IL28B with response to pegylated interferon-alpha and ribavirin therapy for chronic hepatitis C. Nat Genet. 2009;41:1105-9.

7. Asselah T, De Muynck S, Broet P, Masliah-Planchon J, et al. IL28B polymorphism is associated with treatment response in patients with genotype 4 chronic hepatitis C. J Hepatol. 2012;56:527-32.

8. Mangia A, Mottola L, Santoro R. Interleukin 28B plymorphisms as predictor of response in hepatitis $\mathrm{C}$ genotype 2 and 3 infected patients. World J Gastroenterol. 2013;19(47):8924-8.

9. Antaki N, Craxi A, Kamal S, Moucari R, Van der Merwe S, Haffar $S$, et al. The neglected hepatitis $C$ virus genotypes 4,5 and 6: an international consensus report. Liver Int. 2010;30: $342-55$

10. Kamal SM. Hepatitis C virus genotype 4 therapy: progress and challenges. Liver Int. 2011;31:45-52.

11. Mangia A, Thompson AJ, Santoro R, et al. Limited use of interleukin $28 \mathrm{~B}$ in the setting of response-guided treatment with detailed on-treatment virological monitoring. Hepatology. 2011; 54:772-80.

12. Mangia A, Thompson AJ, Santoro R, Piazzolla V, Tillmann HL, Patel K, Shianna KV, Mottola L, Petruzzellis D, Bacca D, Carretta V, Minerva N, Goldstein DB, Mc Hutchison JG. Interleukin28B polymorphism determines treatment response of patients with hepatitis $\mathrm{C}$ genotypes 2 and 3 who do not achieve a rapid virologic response. Gastroenterology. 2010;139:821-7.

13. Mc Carthy JJ, Li JH, Thompson A, Suchindran S, et al. Replicated association between an IL28B gene variant and a sustained response to pegylated interferon and ribavirin. Gastroenterology. 2010;138:2307-14.

14. Eslam M, Leung R, Romero-Gomez M et al. IFNL3 polymorphisms predict response to therapy in chronic hepatitis $\mathrm{C}$ genotype $2 / 3$ infection.

15. Mottola L, Cenderello G, Piazzolla VA, Forte P, Carretta V, Mecenate F, Brancaccio G, Minisini R, Zuin M, Terreni N, Monti M, Colombo AE, Nosotti L, Minerva N, Luzzitelli I, Kostandini A, Cuccorese G, Russello M, Santoro R, Mangia A. Interleukin28B genetic variants in untreated Italian $\mathrm{HCV}$-infected patients: a multicentre study. Liver Int. 2015;35(2):482-8. doi:10.1111/liv. 12630.

16. Abe H, Ochi H, Maekawa T, et al. Common variation of IL28 affects gamma-GTP levels and inflammation of the liver in chronically infected hepatitis $\mathrm{C}$ virus patients. J Hepatol. 2010;53:439-43.

17. Barreiro P, Pineda JA, Rallon N, et al. Influence of interleukin28B single-nucleotide polymorphisms on progression to liver cirrhosis in human immunodeficiency virus-hepatitis $\mathrm{C}$ viruscoinfected patients receiving antiretroviral therapy. J Infect Dis. 2011;203:1629-36.

18. Bochud PY, Bibert S, Kutalik Z, et al. IL28B alleles associated with poor hepatitis $\mathrm{C}$ virus $(\mathrm{HCV})$ clearance protect against inflammation and fibrosis in patients infected with non-1 HCV genotypes. Hepatology. 2012;55:384-94.

19. Ydreborg M, Westin J, Rembeck K, Lindh M, Norrgren H, Holmberg A, Wejstål R, Norkrans G, Cardell K, Weiland O, Lagging M. Impact of Il28b-related single nucleotide polymorphisms on liver transient elastography in chronic hepatitis $\mathrm{C}$ infection. PLoS One. 2013;8(11):e80172. doi:10.1371/journal. pone.0080172.eCollection.

20. Fabris C, Falleti E, Cussigh A, et al. IL-28B rs12979860 C/T allele distribution in patients with liver cirrhosis: role in the course of chronic viral hepatitis and the development of HCC. J Hepatol. 2011;54:716-22.

21. Marabita F, Aghemo A, De Nicola S, Rumi MG, Cheroni C, Scavelli R, Crimi M, Soffredini R, Abrignani S, De Francesco R, Colombo M. Genetic variation in the interleukin-28B gene is not associated with fibrosis progression in patients with chronic 
hepatitis $\mathrm{C}$ and known date of infection. Hepatology. 2011;54(4):1127-34. doi:10.1002/hep.24503 Epub 2011 Aug 19.

22. Noureddin M, Wright EC, Alter H, et al. Association of IL28B genotype with fibrosis progression and clinical outcomes in patients with chronic hepatitis C: a longitudinal analysis. Hepatology. 2013;58:1548-57.

23. Ansaldi F, Bruzzone B, Salmaso S, Rota MC, Durando P, Gasparini R, Icardi G. Different seroprevalence and molecular epidemiology patterns of hepatitis $\mathrm{C}$ virus infection in Italy. $\mathrm{J}$ Med Virol. 2005;76:327-32.

24. Marascio N, Liberto M, Barreca G, Zicca E, Quirino A, Lamberti A, Bianco G, Matera G, Surace L, Berardelli G, Surace L, De Maria V, Giancotti F, Leone R, Villella V, Nisticò S, Borelli A, Caruso V, Calderazzo M, Griffo G, Masciari R, Minchella P, Cosco L, Laganà C, Oliva A, Foti G, Fiorillo M, Bocchiaro G, Surace $\mathrm{P}$, Ciccaglione $\mathrm{A}$, Ciccozzi $\mathrm{M}$, Cesario $\mathrm{F}$, Torti $\mathrm{C}$, Focà $\mathrm{A}$. Update on epidemiology of HCV in Italy: focus on the Calabria Region. BMC Infect Dis. 2014;14(Suppl 5):S2. doi:10.1186/ 1471-2334-14-S5-S2.

25. Derbala M, Rizk N, Shebl F, Alkaabi S, Eldweik N, John A, Sharma M, Yaqoob R, Almohanadi M, Butt M, Alejji K. Interleukin-28 and hepatitis $\mathrm{C}$ virus genotype-4: treatment-induced clearance and liver fibrosis. World J Gastroenterol. 2012;18(47): 7003-8. doi:10.3748/wjg.v18.i47.7003.

26. Muir AJ, Arora S, Everson G, Flisiak R, George J, Ghalib R, Gordon SC, Gray T, Greenbloom S, Hassanein T, Hillson J, Horga MA, Jacobson IM, Jeffers L, Kowdley KV, Lawitz E, Lueth S, Rodriguez-Torres M, Rustgi V, Shemanski L, Shiffman ML, Srinivasan S, Vargas HE, Vierling JM, Xu D, LopezTalavera JC, Zeuzem S. EMERGE study group. A randomized phase $2 b$ study of peginterferon lambda- $1 \mathrm{a}$ for the treatment of chronic HCV infection. J Hepatol. 2014;61(6):1238-46. doi:10. 1016/j.jhep.2014.07.022.

27. Tamaki N, Kurosaki M, Higuchi M, Takada H, Nakakuki N, Yasui Y, et al. Genetic polymorphism of IL28B and PNPLA3 are predictive for $\mathrm{HCV}$ related rapid fibrosis progression and identify patients who require urgent antiviral treatment with new regimens. PLoS One. 2015;10(9):e0137351. doi:10.1371/journal. pone. 0137351 .
28. European Medicines Agency (EMA). Sovaldi registration details. http://www.ema.europa.eu/ema/index.jsp?curl=pages/medicines/ human/medicines/002798/human med 001723.jsp\&mid $=$ WC 0b01ac058001d124. Accessed 06 Feb 2015.

29. U.S. Food and Drug Administration (FDA). Sovaldi registrationdetails. http://www.accessdata.fda.gov/scripts/cder/drugsatf a/index.cfm?fuseaction=Search. DrugDetails. Accessed 12 Feb 2015.

30. European Medicines Agency (EMA). Harvoni registration details. http://www.ema.europa.eu/ema/index.jsp?curl=pages/ medicines/human/medicines/003850/human med 001813.jsp\& mid = WC0b01ac058001d124. Accessed 06 Feb 15.

31. U.S. Food and Drug Administration (FDA). Harvoni registrationdetails. http://www.accessdata.fda.gov/scripts/cder/drugsatf da/index.cfm?fuseaction=Search.DrugDetails.

32. European Medicines Agency (EMA). Daklinza registration details. http://www.ema.europa.eu/ema/index.jsp?curl=pages/ medicines/human/medicines/003768/human med 001792.jsp\& mid = WC0b01ac058001d124. Accessed 06 Feb 15.

33. European Medicines Agency (EMA). Olysio registration details. http://www.ema.europa.eu/ema/index.jsp?curl=pages/medicines/ human/medicines/002777/human med 001766.jsp\&mid = WC0b 01ac058001d124. Accessed 06 Feb 2015.

34. U.S. Food and Drug Administration (FDA). Olysio registrationdetails. http://www.accessdata.fda.gov/scripts/cder/drugsatf $\mathrm{da} /$ index.cfm?fuseaction=Search.DrugDetails.

35. U.S. Food and Drug Administration (FDA). Viekirax ${ }^{\circledR}+$ Exviera registra-tion details. http://www.accessdata.fda.gov/scripts/cder/ drugsatfda/index.cfm?fuseaction=Search.DrugDetails.

36. Fried MW, Buti M, Dore GJ, Flisiak R, Ferenci P, Jacobson I, Marcellin P, Manns M, Nikitin I, Poordad F, Sherman M, Zeuzem S, Scott J, Gilles L, Lenz O, Peeters M, Sekar V, De Smedt G, Beumont-Mauviel M. Once-daily simeprevir (TMC435) with pegylated interferon and ribavirin in treatment-naïve genotype 1 hepatitis C: the randomized PILLAR study. Hepatology. 2013;58(6):1918-29. doi:10.1002/hep.26641.

37. Lawitz E, Mangia A, Wyles D, et al. Sofosbuvir for previously untreated chronic hepatitis C infection. N Engl J Med. 2013; 368(20):1878-87. doi:10.1056/NEJMoa1214853. 